\title{
Creativity and Motivation in Higher Education Teacher Training
}

\section{Jarmila Novotná - L'ubomír Verbovanec - Luboš Török*}

\begin{abstract}
The main research subject of this study is a teacher. Our goal is to contribute to changes in teacher training in the direction of developing their motivation and creative potential, so that creative personalities of students could be subsequently developed. We chose the methodological concept of a natural developing experiment, in which we study the dynamics of changes in motivation and creativity of student teachers. In the scope of extensive research concept we used various methods to record scores before and after the experiment, such as IMB, DMV, IPOT, WKOPAY and Torrance Figural Test of Creative Thinking. The results were subjected to a quantitative evaluation by means of conventional statistical methods, such as the significance of differences in arithmetic means and index analysis. These were subjected to a qualitative analysis. As a result, conclusions were drawn from the study of future teachers' motivation and creativity. The results have shown significant arguments in favour of aimed and intensive motivational and creative development programmes. As it follows from our findings, interesting also for theories on educational process, the elimination of fear, anxiety, tension and teaching stress can humanise educational environment and also change motives for improving one's creative performance. The goal of our experiment is to contribute to the improvement of undergraduate teacher training and participate in progressive changes in the educational system.

Key words: humanistic education, motivation, creativity, creativity and motivation development strategies, undergraduate teacher training, creative programmes and stimulation of creativity and motivation in undergraduate teacher training.
\end{abstract}

\footnotetext{
* Jarmila Novotná, Dubnica Institute of Technology in Dubnica nad Váhom, Dubnica nad Váhom, Slovakia; doc.jn1@gmail.com

Lubomír Verbovanec, Dubnica Institute of Technology in Dubnica nad Váhom, Dubnica nad Váhom, Slovakia; verbovanec@dti.sk

Luboš Török, Constantine the Philosopher University in Nitra, Nitra, Slovakia; ltorok@ukf.sk
} 


\section{Introduction}

At present, the concept of motivation and creativity is associated with almost all modern human activities. They are often mentioned in connection with school and teacher's personality.

The analysis of the term motivation illustrates a wide range of problems and variability of its understanding. Their detailed analysis, however, is not our goal. As many authors (Hrabal, 1989, Pardel, 1977, Szoboiová, 2004, Zelina, 1995 etc.), whose ideas were influenced by foreign "classic authors" and their works, we understand motivation as an aggregate of factors which stimulate, energise and coordinate the process of human behaviour, as well as experiencing relationships between the outside world and themselves.

Therefore, motivation in the educational process has got a dual role. It is a means of learning process and the aim of education at the same time (Sollárová, 1985). It cannot be divided because each change in motivation of learning activity is dependent on the motivational sphere of personality and vice-versa (Torrance, 1988). However, it can be stimulated in many ways. Firstly, the external motivation can be turned into internal motivation. For this reason, it is important to create such atmosphere which would include incentives saturating specific needs. Such stimulated motivation is based on their changes (for example, competing elements in teaching can change the social needs, and on the other hand, problematic teaching can change cognitive needs) (Hlavsa, 1985). Secondly, the motivational component of educational activities is goalsetting and goal-acceptance.

The change in the student's cognitive needs in specific creative teaching conditions can be achieved by problematic and creative tasks. The problem solving can be externally and internally motivated (when the motivation comes from our needs, self-realisation and purposeful learning for oneself). A third possibility also exists in case the task given from the outside is internalised and a man accepts it as his/her own without any pressure from the outside (Jurčová, $1979 ; 1984)$. The entire process of motivational cycle is emotionally and positively harmonised, which is the basis of self-regulation. Satisfying one's needs does not necessarily mean the end of motivation, but the oscillation of its intensity and gradual slower or faster suppression of its level depending on the stimulating effect of the environment. The demand for knowing one's needs, motives and most importantly to motivate a personality to a creative activity in teaching is easier said than done.

Internal motivation is a prerequisite for the development of a creative personality since the biggest factor influencing progressive human self-realisation and realisation as a whole is a dynamic sphere, i.e. motivation, control and creativity. At present, creativity is a significant phenomenon. Therefore, the purpose of our study is contribution to the development of those who will play a major role in 
education of children, youth and future teachers. Teacher training is one of the most discussed topics concerning changes in education round the world today. Our country is also looking for approaches to conceptual changes in teacher training (sometimes these efforts lead only to partial innovations). Mainly in the support or development of activity, independence, and creativity amongst future teachers we see the possibility of conceptual change in education (Königová, 2007; Kusá, 2006). We would like to mention the fact that a systematic, theoretical and experimental research in this area is mostly done by psychologists who prove that certain creative, divergent and productive thinking parameters can be improved by means of creativity programmes, influencing the attitude, creation of creative procedures and methods. Our purpose is also driven in this direction. Its aim is to study and influence the most flexible factor beginning to take part in education, that is, the teacher's personality in creativity.

There is a whole list of proposals on how to support and develop a creative personality. From reflexive practice techniques through observation of student teachers, team teaching, metacommunication, clinical writing, video-practice, life-story writing, simulated situations, role-playing up to the most selfcontained concept of creative teaching (Dargová, 2001). This is aimed at stimulation of the whole creative potential of a personality. It becomes a human imperative.

We distinguish two trends in approaches to the stimulation of a creative teacher's personality. (Biehler - Snowman, 1990) The first one outlines the way to eliminate obstacles of a creative expression of a personality. The second one prioritises the awakening, stimulation and creativity cultivation. Creative programmes belong to relatively new possibilities. Their advantage is that they are less unrestrained, less dispersed, which enables us to study their effects more thoroughly. In the end, our research is connected with the attempt to develop such a programme and subsequently to verify it experimentally. Dynamic and synthesising nature of creativity as a human tendency to realise one's capabilities and possibilities were situated into the programme, which indicates and respects the particularities of developing creativity amongst future teachers in undergraduate teacher training. The first particularity is perceived in terms of creativity stimulation of future teachers. In this case, creativity has got two stages. The first one focuses on the development of general creative abilities, such as figural, verbal, behavioural creativity on the level of fluency, flexibility and originality (Guilford's model). The second one is applicative, that is we assign such tasks and cases which are taken directly from educational life supposing that a teacher will be able to do something similar in practice (for example, student - teacher relationship, climate, curriculum etc.). The second particularity means that as far as creativity is stimulated and developed in a personality, it is usually cognitive creativity, intellectual creativity and creativity in thinking. However, a teacher must be creative not only in thinking, 
but also in feelings, motivation, socialisation, communication, cooperation etc. Therefore, we cannot focus only on mental and cognitive creativity, but we should extend it beyond the borders of creative abilities in the manner of behavioural style of the future teachers.

We consider the aforementioned to be the basic starting point of this creative programme formulation, which was named Creative Teacher (Marušincová, 1989). We respected the real university conditions. The key elements were creative tasks which are motivating (including collative properties, such as surprisingness, newness, curiosity, frequent drama during assignment of tasks, cognitive insecurity connected with a contradiction of the problem formulation, difficulty and also trust or confidence found in a personality, the problem solving and its constant encouragement focusing on the development of fluency, flexibility, originality, imagination, emotions, (Jurčová, 1993) evaluative thinking, strategies, such as a creative game, staging and situational methods) and creative climate (creativity is developed in the climate of truthfulness, trust, self-confidence, security and strategies, such as improvisation, pantomime, sociodrama etc.).

The Creative Teacher programme included three inter-related parts:

The first one focused on creation of a favourable socio-creative climate (these exercises help increase self-confidence of a personality in the group; activities are usually simple, non-contrastive, funny, but they begin the process of introspection, i.e. insight into oneself).

In the second part the attention was focused on the "self-concept" of personality, that is, on "I" as a starting point for self-knowledge, trying to find oneself, introspection and identifying emotions, self-awareness (exercises are aimed at a cognitive, emotional, evaluative, active or conative area of self-awareness; students should understand and realise the fact that their selfawareness structure creates an aggregate of a real image about themselves a conviction associated ideas of an individual on how they accept their current tasks, roles etc.); social image (a conviction associated with images of an individual on how others see and perceive it) and individual image (images of who they wish to become); acceptance, congruence and empathy are seen as an organic part of a human self-concept.

The third one was a shift towards educational practice of a future teacher. It is focused on the development of creativity and creative cooperation in a group. Not only mental functions and processes of the future teacher's personality, but also the philosophy of a creative life are practised, that is, creative feelings, motivation towards learning and creativity, creativity in socialisation, human relationships, creativity in axiology and metacreativity.

Before demonstrating the results of our experiment we would like to point out the fact that the issue of creativity and motivation is not to be considered completely examined. Therefore, the results that we came up with cannot be absolute, and so we are open to the given issue. 


\section{Methodology and research methods}

\section{1 Research goals}

In connection with a theoretical basis of motivation and creativity study in terms of education and our research intention, we were interested in answers to the following questions:

What motivation is a prerequisite for the development of creativity in student teachers? Which motives prevail? What are the standpoints of future teachers towards creativity? How do they judge themselves in terms of creativity? What creative potential do they really have? Is it possible that stimulation and creative performance in teacher training as such can be changed intentionally? If so, how?

The main goal was to experimentally verify the effectiveness of our programme called Creative Teacher in undergraduate teacher training, that is to study the dynamics in motivational changes, in self-evaluation of creativity and most importantly in the creative performance of future teachers.

The secondary goal was to create the Creative Teacher programme, which would support motivation towards creativity and, at the same time, develop a creative potential of future teachers in natural conditions of their undergraduate study.

The complex goal was to direct future teachers towards self-changing tendency, which would lead to creation of such competencies that are required for progressive changes in the current educational system.

\section{2 Research problems}

The main problem was to create a programme which would motivate and stimulate a creative potential of future teachers. In connection with this problem, we tried to solve the issue of motivational and developing programme elements, their adequacy and effectiveness. It was not a simple task to think through the time available for implemented changes which should be shown. Another problem was seen how objectively we can evaluate such changes. The objective evaluation of these changes was also perceived as a stumbling block. In relation to this, we have to consider and choose such performance and self-evaluation methods or tests, by means of which we could find out motivation, selfjudgement of the students' creativity and their creative performance. The following questions came to mind in these terms: Will the programme be manifested in the given tests? Will the specific transfer occur? Which nonspecific transfers will occur?

Another challenging problem of our experiment was the interpretation of the obtained results and data. Since both motivation and creativity are psychological phenomena, our research was interdisciplinary oriented. The research, but also the interpretative scope had a psychodidactic character. 


\section{3 Research tasks}

- to create a programme called Creative Teacher with a dominant position of methods, techniques and strategies for cognitive motivation, tasks with collative variables, creative problem solving and creative personality characteristics which would develop creativity itself;

- to prepare and choose methods, techniques and strategies in order to verify the effectiveness of our Creative Teacher programme;

- to choose a research sample;

- to discover score in affective, cognitive and effective motives of motivation amongst students and study their dynamics of changes under the influence of the programme in the direction of their changing tendency;

- to discover changes in creativity performance, i.e. on the level of creative abilities in factors, such as fluency, flexibility and originality before and after the experiment;

- to evaluate the effectiveness of the experiment by means of statistical processing of the results and qualitative analysis.

\section{4 Hypotheses}

In connection with the research goals we set a general hypothesis:

H: We assume the Creative Teacher programme will significantly affect the development of motivation and creativity in the experimental group compared to the control group.

From the general hypothesis we deduced the following hypotheses:

H1: Under the influence of the Creative Teacher programme in the experimental group the total score of motivation in learning (score in affective, cognitive and effective motives) will statistically increase.

H2: By implementing the Creative Teacher programme in the experimental group the attitude of the students towards creativity and self-judgment of their own creative prerequisites will be significantly changed.

H3: By implementing the Creative Teacher programme in the experimental group a creative performance within factors of fluency, flexibility and originality will significantly increase.

\section{5 Nature of research}

From the standpoint of our research goal we chose an experiment that is defined as a type of empirical research in which a researcher manipulates and controls one or more variables (independent variables) and observes dependent variables in relation to the accompanying changes. These changes in the dependent variables are caused by manipulation with the independent variables. Although it takes a lot of time and organisation, it is most accurate. It also enables us to observe the relevant variables in the time dimension. The ex ante measurement 
allows to equalise the samples of both groups upon the beginning of the experiment or eventually to control the initial variables. Its methodological advantage is seen in the fact that it enables us to study several variables at the beginning and at the end of the experiment and also to combine self-evaluation methods, which are more focused on experiencing (WKOPAY) along with performance measures (IMB, CIRCLES).

The control of systematic external dispersion (the effect of unwanted independent variables) was secured by random assignment of conditions to the experimental groups.

Since the groups were equal at the beginning, the conditions of EG and CG were randomly assigned to them.

\section{6 Research methods}

For data retrieval the following methods have been used:

$\boldsymbol{I M B}$ - questionnaire on the motivation to learning - by the Hungarian author Béla Kozéki. It determines the overall level of a student's motivation to knowledge acquisition, i.e. also to self-improvement. In addition, it tracks the structure of motivation, the dominant triad, in three areas: cognitive, affective and effective. Its advantage is the fact that students mark only those motifs that really influence their learning process. It is based on the theory of external and internal motivation. It is created specifically for students and the school and determines the most significant motives derived from factor analyses of the students' motivational structures.

WKOPAY - What Kind Of Person Are You? - is a questionnaire on the selfevaluation of one's personality creative potential created by Torrance and Khatena and it was adapted to our conditions by Zelina (he changed the names of some factors, so that they correspond better to the question wordings, etc.). The questions arranged in pairs are being repeated in a modified form always with a new question in the pair and the subject has to choose one of the alternatives. Five personality factors are monitored which according to the theory by Torrance and Khatena condition creativity: self-confidence, inquisitiveness, intuition, industriousness and awareness of others. The authors assumed that the higher the score in these five personality factors is, the more do the participants evaluate themselves with higher personality creative potential.

TTCT - Torrance Test of Creative Thinking - consists of three figural tests. From this set we have chosen the subtest CIRCLES, which was prepared with the norms on the Slovak population by Jurčová. Such a test has proven suitable in determining the participants' ability to produce divergent figural units. It assesses the fluency, flexibility, and originality of the productions. The results between control and experimental groups and between ex ante and ex post measurements can be compared.

For the processing and analysis of the data, the following statistical methods have been used: 
Paired t-test used for dependent samples tests the difference in mean values in one group (between ex ante and ex post). We have used it to determine if the difference in mean values is random or statistically significant. Unpaired t-test used for independent samples tests the difference in mean values of two groups (between EGs and CGs). We have used it to determine if the difference in mean values is random or statistically significant.

Unpaired and paired t-tests may be also used with small samples $(<50)$, but only when the assumption of normal distribution is met and the variances of these groups do not differ significantly. Normality has been determined by the normality test. If the test rejects normality, we use the non-parametric alternative, the Mann-Whitney $\mathbf{U}$ test which tests the difference in medians (which was also our case).

The qualitative interpretation of our findings was difficult, since we were in an interdisciplinary (psycho-pedagogical) research field. Therefore, we carried out not only the quantitative but also qualitative, causal and descriptive analyses.

\section{7 Research sample}

The research was carried out at the University of Prešov, in particular at the Faculty of Humanities and Natural Sciences in Prešov. When choosing the research respondents, we assigned the conditions of control experimental groups to already existing student groups, to the so-called clusters, and not individuals. This means that we use the cluster or group selection. To ensure the representative character of the retrieved data, we adhere to the following conditions: the experimental and control groups are the same size and are internally homogenous.

Altogether, 188 participants joined the research: 96 students in two EGs and 92 in two CGs. Such a choice and arrangement of the sample was due to the changes in teacher training at the UP in relation to the internal reform of universities and the changes in contents and time allocation of the pedagogicalpsychological disciplines. One CG and EG took courses according to an original programme of teacher training and the second CG and EG according to a new programme. We have divided and labelled the sample as follows:

- The students of "core courses" (later only CC) - the groups CG_CC (44 students) and EG_CC (51 students) in the original study programme named "core courses".

- The students of "social studies and pedagogical-psychological essentials" (later only SSPPE) - the groups CG_SSPPE (48 students) and EG_SSPPE (45 students) in the new programme of training future teachers.

We carried out the experiment in two semesters in each experimental group and in the natural conditions of the university undergraduate teacher training. The students CC_EG took part in the Creative Teacher programme as a part of the following subjects: intro to didactics and general pedagogy and psychology of 
creativity and the students SSPPE_EG took part in the Creative Teacher programme as a part of the following subjects: general didactics and cooperative teaching. The experimental groups were taught by a university lecturer associate professor (docent) with $\mathrm{PhD}$. In the control groups, where the programme was not implemented, the teaching was carried out by traditional methods by a university lecturer with $\mathrm{PhDr}$. or $\mathrm{PhD}$. The guarantor of the contents of all the listed subjects was associate professor (docent) with $\mathrm{PhD}$. The experiment was carried out in the range of 40 forty-five-minute lessons over two semesters. The third part consisted of a block of 6 forty-five-minute lessons ( 3 two-hour lessons) carried out in extracurricular time. The overall programme range was 52 lessons. As undesirable variables in the experiment, we eliminated the influence of environment and communication between students mainly by optical cross-comparisons of both control and experimental groups according to the original and current study plans.

The variables that have been chosen for the expected changes in the experiment were a part of the programme for creativity development in undergraduate teacher training. They include different motivational strategies, therapeutic techniques, divergent tasks and activations of evaluative and self-evaluative thinking.

\section{8 Research procedure}

The input for our experiment with ex ante and ex post measures in EGs and CGs included an overview of theoretic and research-based creativity problems, the definition of objectives and hypotheses and the assignment of a methodological approach for our research. Afterwards we prepared a block of tests for measuring the relevant variables.

Subsequently, we carried out initial measurements in all groups in the range of one week. The instructions and motivation to the individual tests were standardised and compliant with the mentioned procedures.

After the initial measurement, the Creative Teacher programme was carried out in the experimental groups. In the control groups, the university teaching continued in a traditional way, i.e. the lectures and seminars prevailed. The lectures were dominated by the explanations of topics from the subject syllabus and the seminars included the usual essays and thematic presentations. The lessons were focused on What? (e.g. What is creativity? What are the methods for creativity development? etc.), not on How? In some of the CG seminars the experience methods, solving and modelling of problem situations and teamwork were also used, but their choice was intuitive and random, in accordance with the topic of the lesson.

After the experiment, we carried out output measurements in all the EGs and CGs. This measurement was done under the same conditions and with the same instructions as the initial one but this time we wanted to determine the changes that occurred due to the elapsed time and due to the influence of the programme. 
These steps provided us with material for the quantitative and qualitative analysis.

\section{Results and survey interpretation}

\section{1 Motivation for teaching}

We begin the interpretation of data with an IMB survey by means of which we seek to prove or reject the first hypothesis. We hypothesise that the creativity development programme will help improve the overall motivation in all three of its constituent parts, i.e. cognitive, affective and effective. An IMB survey has been used in the testing of variables. The scores, as shown in the following tables, can very well reach a minus value as negative-value answers are to be subtracted from positive-value ones.

\begin{tabular}{|c|c|c|c|c|c|c|c|c|c|}
\hline \multicolumn{4}{|c|}{ Motivation IMB } & \multicolumn{5}{c|}{ Motivation IMB } \\
(CC_before experiment)
\end{tabular}

Tab. 1 Motivation of students measured by IMB questionnaire before the experiment

Legend for Table 1 - 4

mean-arithmetic mean

deviation - standard deviation

$t$-test - statistical significance of differences

$*$ - statistical significance of differences on level $\alpha=0.05$ (95\%)

$* *$ - statistical significance of differences on level $\alpha=0.01(99 \%)$

*** - statistical significance of differences on level $\alpha=0.001$ (99.9\%) 
In Table 1 we summarise the results of evaluation in groups $\mathrm{CC}_{-} \mathrm{CG}$ and EG, and SSPPE_CG and EG before the experiment. In studying motivation we have noticed no statistically significant variance between $\mathrm{CC}_{-} \mathrm{CG}$ and $\mathrm{CG}$ within the entire motive triad. However, we have observed very low levels of motivation with all three variables. An interesting fact is that at the beginning of the evaluation group CC_CG exhibited a dominance of affective motivation over cognitive and effective, whereas in group CC_EG cognitive motivation prevailed over affective and effective. In group SSPPE_CG effective motivation seems to be the most prominent one, followed by effective and cognitive. Even so, the differences are not statistically relevant. The value order of the variables with EG_SSPPE is the same as in the control group, which proves the similarity of both groups. Ex ante and ex post measurements with group CC_EG after the experiment are shown in Table 2.

\begin{tabular}{|c|l|c|c|c|c|}
\hline \multicolumn{7}{|c|}{ Cotivation IMB } \\
\hline & & affective & cognitive & effective & total \\
\hline \hline $\begin{array}{c}\text { experimental } \\
\text { group (ex } \\
\text { ante) }\end{array}$ & mean & 5.11 & 5.18 & 5.03 & 15.84 \\
\cline { 2 - 6 } & deviation & 0.99 & 0.97 & 0.89 & 2.4 \\
\hline \hline $\begin{array}{c}\text { experimental } \\
\text { group (ex } \\
\text { post) }\end{array}$ & mean & 5.92 & 7.14 & 6.22 & 19.02 \\
\cline { 2 - 7 } & deviation & 1.37 & 1.12 & 1.11 & 3.3 \\
\hline \hline t-test & $3.222^{* *}$ & $8.949^{* * *}$ & $5.643^{* * *}$ & $5.241^{* * *}$ \\
\hline
\end{tabular}

Tab. 2 Motivation of CC_EG students measured by IMB questionnaire before and after the experiment

The data demonstrate the following:

The order of variables in group EG_CC has changed after experimental interference. While cognitive motivation still dominates, effective and affective motivations have swapped positions. We have, however, not assessed the statistical relevance of the changes since the scope and aims of our research required an assessment of the overall motivation rise. Still, these results may very well become a basis for further research. After comparing ex ante and ex post measurements, we claim that effective motives with EG_CC have risen in prominence. The rise of value from 5.11 to 5.92 represents a 0.01 significance level. In order to prove hypothesis 1 it was also necessary to assess the score rise with cognitive and effective motivation. Effective motivation based on the comparison between ex ante and ex post measurements has reached $0.001 \%$ significance. This is based on the average change from 5.03 to 6.22. Cognitive motivation, displaying the highest value right from the start, has in average 
shifted from 5.18 to 7.14 in the course of the experiment, which stands for a 0.001 significance level. It is the cognitive motivation which interests us mostly both in this study and in the programme we are promoting. It is the motivation which definitely plays a key role both in teaching and in learning to be creative. The willingness to learn and gain knowledge is important in the development of individual creativity.

The overall score of motivation has reached a $0.001 \%$ significance level in ex ante and ex post measurements and this proves hypothesis 1 .

Since our experiment entailed the participation of two experimental groups, ex ante and ex post measurements have been used with group SSPPE as well. Based on the measurements, the following has been demonstrated (Table 3):

\begin{tabular}{|c|c|c|c|c|c|}
\hline \multicolumn{7}{|c|}{ Motivation IMB } \\
\hline \hline & & affective & cognitive & effective & total \\
\hline \hline \multirow{2}{*}{$\begin{array}{c}\text { experimental } \\
\text { group ( ex } \\
\text { ante) }\end{array}$} & mean & 5.07 & 4.76 & 4.79 & 14.61 \\
\cline { 2 - 6 } & deviation & 1.18 & 1.07 & 0.97 & 2.97 \\
\hline \hline $\begin{array}{c}\text { experimental } \\
\text { group (ex } \\
\text { post) }\end{array}$ & mean & 5.87 & 6.13 & 5.96 & 18.43 \\
\cline { 2 - 6 } & deviation & 1.03 & 1.28 & 1.07 & 3.12 \\
\hline \hline t-test & & $3.436^{* * *}$ & $5.552^{* * *}$ & $5.470^{* * *}$ & $5.983^{* * *}$ \\
\hline
\end{tabular}

\section{Tab. 3 Motivation of SSPPE_EG students measured by IMB questionnaire before and after the experiment}

By means of experimental interference the order of variables has changed with group EG_SSPPE. Before interfering, affective motivation evidenced the highest values, followed by effective and cognitive. After interfering, cognitive motivation has earned the highest score, followed by effective and affective. Even so, it cannot be said that the creativity development programme has influenced the order of variables. This is because the order of variables has changed in the control groups as well, and this happened without the adoption of the programme. Yet our goal is to trace down constituent parts of motivation. One of them is affective motivation which has shown the lowest increase of the variables (see Table 4). Regardless of that, with its average difference between 5.07 and 5.87 at the final measurement it has reached a relevance level of 0.001 . Cognitive motivation has been rising most notably of all the variables (4.76 at the start, 6.13 at the end). The statistical relevance of the values is 0.001 . With effective motivation, we have also noticed a significant rise (4.99 at the start, 5.96 at the end) which equals a relevance level of 0.001 . The overall motivation has increased on a 0.001 level after the application of our programme. 
To reach a full account of the data after the experiment we decided to compare the results from the control and experimental groups. This enabled us to verify the hypothesis about the effectiveness of the programme. The data is summarised in Table 4.

\begin{tabular}{|c|c|c|c|c|c|c|c|c|c|}
\hline \multicolumn{6}{|c|}{$\begin{array}{c}\text { Motivation IMB } \\
\text { CC after experiment }\end{array}$} & \multicolumn{4}{|c|}{$\begin{array}{c}\text { Motivation IMB } \\
\text { SSPPE after experiment }\end{array}$} \\
\hline & & $\begin{array}{l}\text { affect } \\
\text { ive }\end{array}$ & $\begin{array}{c}\text { cogni } \\
\text { tive }\end{array}$ & $\begin{array}{l}\text { effec } \\
\text { tive }\end{array}$ & total & $\begin{array}{c}\text { affec } \\
\text { tive }\end{array}$ & $\begin{array}{l}\text { cogn } \\
\text { itive }\end{array}$ & effective & total \\
\hline \multirow{2}{*}{$\begin{array}{c}\text { control } \\
\text { group }\end{array}$} & mean & 5.07 & 4.73 & 4.87 & 15.1 & 4.35 & 4.41 & 4.28 & 13.1 \\
\hline & $\begin{array}{l}\text { devia } \\
\text { tion }\end{array}$ & 1.49 & 1.08 & 1.04 & 3.4 & 1.19 & 1.21 & 1.13 & 3.23 \\
\hline \multirow{2}{*}{$\begin{array}{c}\text { experim } \\
\text { ental } \\
\text { group }\end{array}$} & mean & 5.92 & 7.14 & 6.22 & 19.02 & 5.87 & 6.13 & 5.96 & 18.43 \\
\hline & $\begin{array}{l}\text { devia } \\
\text { tion }\end{array}$ & 1.37 & 1.12 & 1.11 & 3.3 & 1.03 & 1.28 & 1.07 & 3.12 \\
\hline t-test & & $2.865^{*}$ & 10.520 & 6.021 & 5.633 & $6.496^{*}$ & 6.589 & $7.727^{* * *}$ & 7.997 \\
\hline
\end{tabular}

Tab. 4 Motivation of students measured by IMB questionnaire after the experiment

As we compared the results between the control groups before and after the experiment, we have noticed almost no differences in the variables, although the students from both the control and experimental groups were taking the same study plan. However, the order in the motivation triad has changed. Before the experiment, affective motivation dominated over effective and cognitive in group $\mathrm{CG}_{-}$SSPPE. After the experiment, affective motivation has still proved the most prominent, followed by cognitive and effective. Affective motivation has reached an average value of 4.35 in group $\mathrm{CG}_{-}$SSPPE, whereas in group EG_SSPPE, which has participated in the Creative Teacher programme, it has reached the value of 5.87. This adds up on a 0.001 significance level. The statistics of affective motivation have increased in both CC and SSPPE experimental groups. Based on the data provided in Table 4, we can say that a statistically relevant increase in EGs over CGs has occurred. With the second examined variable, cognitive motivation, we have seen a significant increase in value (4.41 in CGs compared with 6.13 in EGs). The given values have been evaluated by means of a t-test on significance level of 0.001 . We have seen a 
statistically relevant change in cognitive motivation and this leads to prove hypothesis 1 .

After the implementation of the Creative Teacher programme, the overall motivation of EGs has increased in the way we hypothesised. The increase has reached a significance level of 0.001 , which proves that the Creative Teacher programme has visibly affected the given variables.

Conclusions from the verification of hypothesis 1 :

1. After the experiment conducted with two EGs, the score in cognitive, effective and affective motivation has risen in both ex ante and ex post measurements. A score rise has also been proved when the results of ex post measurements in CGs and ESs were compared. This proves hypothesis 1 .

2. Cognitive motivation score has been changing most significantly. Cognitive motivation has risen where affective motivation decreased.

\section{2 Self-evaluation of creativity}

\begin{tabular}{|c|c|c|c|c|c|c|c|c|c|c|c|c|c|}
\hline \multicolumn{8}{|c|}{$\begin{array}{c}\text { WKOPAY } \\
\text { CC_before experiment }\end{array}$} & \multicolumn{6}{|c|}{$\begin{array}{c}\text { WKOPAY } \\
\text { (SSPPE_before experiment) }\end{array}$} \\
\hline & & $\begin{array}{r}\text { SF } \\
\text { C }\end{array}$ & $\begin{array}{l}\text { IN } \\
\mathbf{Q}\end{array}$ & $\begin{array}{l}\text { IN } \\
\text { T }\end{array}$ & $\begin{array}{l}\text { IN } \\
\text { D }\end{array}$ & $\begin{array}{l}\mathbf{A} \\
\mathbf{W} \\
\mathbf{R}\end{array}$ & total & \begin{tabular}{|l} 
SF \\
C
\end{tabular} & $\begin{array}{l}\text { IN } \\
\mathbf{Q}\end{array}$ & $\begin{array}{l}\text { IN } \\
\text { T }\end{array}$ & $\begin{array}{l}\text { IN } \\
\text { D }\end{array}$ & $\begin{array}{l}\mathbf{A} \\
\mathbf{W} \\
\mathbf{R}\end{array}$ & total \\
\hline \multirow{2}{*}{$\begin{array}{l}\text { control } \\
\text { group }\end{array}$} & $\begin{array}{c}\text { arithmetic } \\
\text { mean }\end{array}$ & 6.93 & 11.34 & 3.88 & 4.97 & 5.46 & 32.78 & 7.11 & 9.86 & 4.33 & 5.26 & 7.03 & 34.1 \\
\hline & $\begin{array}{l}\text { standard } \\
\text { deviation }\end{array}$ & 3.18 & 2.97 & 2.93 & 2.11 & 2.58 & 13.32 & 2.73 & 2.39 & 3.02 & 2.05 & 3.12 & 13.11 \\
\hline \multirow{2}{*}{$\begin{array}{l}\text { experimental } \\
\text { group }\end{array}$} & $\begin{array}{c}\text { arithmetic } \\
\text { mean }\end{array}$ & 7.09 & 10.48 & 3.74 & 5.39 & 4.91 & 32.05 & 6.99 & 8.97 & 5.07 & 5.73 & 6.65 & 33.95 \\
\hline & $\begin{array}{l}\text { standard } \\
\text { deviation }\end{array}$ & 3.34 & 3.22 & 2.49 & 2.37 & 2.83 & 14.05 & 2.47 & 2.16 & 2.73 & 2.17 & 3.36 & 12.69 \\
\hline t-test & & 0.24 & 1.331 & 0.249 & 0.896 & 0.973 & 0.256 & 0.22 & 1.86 & 1.223 & 1.062 & $\begin{array}{c}0.5 \\
6\end{array}$ & 0.055 \\
\hline
\end{tabular}

Tab. 5 Motivation of students measured by WKOPAY questionnaire before the experiment

Legend for Table $5-8$

sfc-self-confidence

inq, - inquisitiveness

int. - intuition

ind. - industriousness

awr-awareness of others

t-test - statistical significance of differences

$* *$ - statistical significance of differences on level $\alpha=0.05(95 \%)$

$* *$ - statistical significance of differences on level $\alpha=0.01(99 \%)$

$* * *$ - statistical significance of differences on level $\alpha=0.001(99.9 \%)$ 
The WKOPAY test has been adopted to prove or reject hypothesis 2 . This test uses five variables closely related to creative skills, namely industriousness, selfconfidence, inquisitiveness, awareness of others and intuition. In order to verify what we hypothesise we conducted initial measurements in EGs and CGs of groups CC and SSPPE. The summarised data from the creativity self-evaluation tests is shown in Table 5 .

With self-confidence, closely related to creativity self-evaluation, all examined groups have shown the second highest variable score. Inquisitiveness has reached the highest score of variables. On the contrary, intuition, a quality enabling us to intuitively make the right decisions, has scored the lowest. With industriousness and awareness of others no statistically relevant difference between the groups has been proved. Such results lead us to believe that, interestingly enough, groups EG_CC_SSPPE and CG_CC_SSPPE act very alike in self-evaluating creativity.

A summarised overview of the EG_CC results is provided in Table 6 and 7. The following has been demonstrated:

With self-confidence in EGs the score has risen from ex ante 7.09 to ex post 10.41 . The difference is on significance level 0.001 . The creativity development programme has stimulated both the evaluation of one's qualities and the selfconfidence in coping with creative tasks. Inquisitiveness has also increased, reaching a significance of 0.001 , which leads to conclude that the students have become much more interested and enthusiastic about the new teaching methods. It is intuition which has increased the most - from an average of 3.74 to 9.06. This also represents a significance of $0.001 \%$. On the other hand, industriousness has exhibited the lowest difference between initial and final measurements, having ended up on significance level $0.05 \%$. This variable represented the all-important ability to work under pressure. Teachers are under continuous, long-term pressure in the workplace, so based on the results from our experiments, we assume that future teachers can cope with frustration. The awareness of others variable has increased greatly after the experiment, from 4.91 to 8.23 . It is a statistically significant difference of 0.001 . The overall selfevaluation of creativity in EG_CC has reached an ex-ante-ex-post statistically significant difference on level $0.001 \%$.

The influence of the creativity development programme has proved to be statistically significant in all variables, most notably with awareness of others and least notably with industriousness. This result has come up in all of the examined groups after ex ante and ex post measurements. The overall creativity self-evaluation of students based on the comparison between groups CG and EG_CC has reached a level of 0.001 . This result can be taken as factual proof of hypothesis 2 .

The experiment results with group EG_SSPPE are visualised in Table 6 and Table 7. We interpret them in the following way: 
Self-confidence has reached a statistical significance level of 0.001 . With inquisitiveness we see the highest increase between the average ex ante (8.97) and ex post (14.37), which stands for a 0.001 significance level. Even though the average difference between intuition values is not as high as with the previous variables, it also bears evidence of the influence of the creativity development programme. The significance is 0.001 . Industriousness and awareness of others exhibit levels of statistical significance of 0.05 and 0.01 respectively. Although they have reached a lower level of statistical significance, we still may consider them relevant and appropriate enough to back the hypothesis. The overall creativity self-evaluation with group EG_SSPPE, as with EG_CC, has reached a significance level of 0.001 . This result does in fact prove hypothesis 2 which claimed that our programme will improve the participants' creativity selfevaluation.

For correct verification of hypothesis 2 we have compared the results of CG and EG_SSPPE after the experiment and these are shown in Table 7. The differences between the CG and EG_ SSPPE variables have reached the level of statistical significance. The overall score in the creativity self-evaluation of students after comparing groups CG and EG_SSPPE is significant. The increase is proof of hypothesis 2 . The increase proves hypothesis 2 .

\begin{tabular}{|c|c|c|c|c|c|c|c|c|c|c|c|c|c|}
\hline & $\mathrm{CC} \mathrm{b}$ & $\begin{array}{r}\mathrm{V} \\
\text { efore }\end{array}$ & $\begin{array}{l}\text { VKOP } \\
\text { ind aft }\end{array}$ & $\begin{array}{l}\mathbf{A Y} \\
\text { er exp }\end{array}$ & rimen & & & SSPI & E bef & $\begin{array}{l}\mathbf{W K O} \\
\text { ore anc }\end{array}$ & $\begin{array}{l}\text { PAY } \\
\text { after }\end{array}$ & experi & ment \\
\hline & & SFC & INQ & INT & IND & AWR & total & SFC & INQ & INT & IND & AWR & total \\
\hline experime & $\begin{array}{l}\text { arithmeti } \\
\text { c mean }\end{array}$ & 7.09 & 10.48 & 3.74 & 5.39 & 4.91 & 32.05 & 6.99 & 8.97 & 5.07 & 5.73 & 6.65 & 33.95 \\
\hline $\begin{array}{c}\text { ntal } \\
\text { group } \\
\text { (ante) }\end{array}$ & \begin{tabular}{|c} 
standar \\
$\mathrm{d}$ \\
deviati \\
on \\
\end{tabular} & 3.34 & 3.22 & 2.49 & 2.37 & 2.83 & 14.05 & 2.47 & 2.16 & 2.73 & 2.17 & 3.36 & 12.69 \\
\hline experime & $\begin{array}{l}\text { arithmeti } \\
\text { c mean }\end{array}$ & 10.41 & 13.82 & 9.06 & 6.68 & 8.23 & 48.6 & 10.17 & 14.37 & 8.14 & 7.06 & 8.91 & 49.24 \\
\hline $\begin{array}{l}\text { group } \\
\text { (post) }\end{array}$ & $\begin{array}{c}\text { standar } \\
\mathrm{d} \\
\text { deviati } \\
\text { on }\end{array}$ & 4.11 & 3.82 & 3.21 & 2.95 & 3.11 & 16.9 & 3.76 & 4.13 & 2.54 & 2.66 & 3.28 & 16.07 \\
\hline t-test & & $4.231^{*}$ & $4.518^{*}$ & $\begin{array}{c}8.825^{*} \\
* *\end{array}$ & $2.300^{*}$ & $\underset{* *}{5.351^{*}}$ & $\begin{array}{c}5.087^{*} \\
* *\end{array}$ & ${ }_{* *}^{4.796^{*}}$ & $\underset{* *}{7.884^{*}}$ & $\underset{* *}{5.544^{*}}$ & $2.620^{*}$ & $\begin{array}{c}3.243^{*} \\
*\end{array}$ & $\begin{array}{c}5.053^{*} \\
* *\end{array}$ \\
\hline
\end{tabular}

Tab. 6 Self-evaluation of students' creativity measured by WKOPAY questionnaire before and after the experiment 


\begin{tabular}{|c|c|c|c|c|c|c|c|c|c|c|c|c|c|}
\hline \multicolumn{8}{|c|}{$\begin{array}{c}\text { WKOPAY } \\
\text { CC CG_EG after experiment }\end{array}$} & \multicolumn{6}{|c|}{$\begin{array}{c}\text { WKOPAY } \\
\text { SSPPE CG_EG after experiment }\end{array}$} \\
\hline & & SFC & INQ & 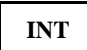 & IND & AWR & total & 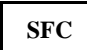 & INQ & 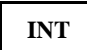 & IND & AWR & Total \\
\hline \multirow{2}{*}{$\begin{array}{l}\text { control } \\
\text { group }\end{array}$} & $\begin{array}{c}\text { arithme } \\
\text { tic } \\
\text { mean }\end{array}$ & 6.88 & 11.15 & 4.08 & 5.31 & 4.82 & 32.64 & 6.98 & 9.33 & 5.13 & 5.21 & 6.83 & 34.06 \\
\hline & $\begin{array}{c}\text { stand } \\
\text { ard } \\
\text { deviati } \\
\text { on }\end{array}$ & 3.69 & 3.58 & 2.97 & 3.11 & 3.03 & 16.08 & 4.01 & 3.99 & 2.82 & 3.14 & 3.34 & 17.01 \\
\hline \multirow{2}{*}{$\begin{array}{l}\text { experim } \\
\text { ental } \\
\text { group }\end{array}$} & $\begin{array}{c}\text { arithme } \\
\text { tic } \\
\text { mean }\end{array}$ & 10.41 & 13.82 & 9.06 & 6.68 & 8.23 & 48.6 & 10.17 & 14.37 & 8.14 & 7.06 & 8.91 & 49.24 \\
\hline & $\begin{array}{c}\text { standar } \\
\mathrm{d} \\
\text { deviati } \\
\text { on }\end{array}$ & 4.11 & 3.82 & 3.21 & 2.95 & 3.11 & 16.9 & 3.76 & 4.13 & 2.54 & 2.66 & 3.28 & 16.07 \\
\hline t-test & & $4.329^{* * *}$ & $3.460^{* * * *}$ & $7.722^{* * * *}$ & $2.178^{*}$ & $5.336^{* * *}$ & $4.644^{* * * *}$ & $3.908^{* * * *}$ & $5.920^{* * * *}$ & $5.338^{* * * *}$ & $3.023^{* * *}$ & $2.994^{* *}$ & $4.369^{* * * *}$ \\
\hline
\end{tabular}

Tab. 7 Self-evaluation of students' creativity measured by WKOPAY questionnaire after the experiment

Conclusions from the verification of hypothesis 2 :

1. Executing our experiment in which we implemented the Creative Teacher programme the level of self-assessment of one's own creative assumptions has increased in both experimental groups. It has been proved not only in the ex post evaluation of both experimental groups, but also in comparison of control and experimental groups in ex ante and ex post measurements.

2. Interesting from the point of view of dominance of variables, the highest score has gained curiosity over self-consciousness. These variables had the highest score before and after the experiment, hence the effectiveness of the programme is not related to the order of studies variables. The mentioned fact can serve as an inspiration for further research.

\section{3 Changes in creative performance}

In order to assess students' creative performance, the figural test of creativity Circles - has been applied. It has been used to verify the third hypothesis in which we presumed the effectiveness of the Creative Teacher programme in creative performance, especially in the factor of flexibility, fluency and originality. In connection to these findings, we do not consider this method in our experiment as a priority. By its implementation we executed a preliminary testing in CC and SSPPE samples. The findings are shown in Table 8. 


\begin{tabular}{|c|c|c|c|c|c|c|c|c|c|}
\hline \multicolumn{6}{|c|}{$\begin{array}{c}\text { CIRCLES } \\
\text { CC_CG_EG before experiment }\end{array}$} & \multicolumn{4}{|c|}{$\begin{array}{c}\text { CIRCLES } \\
\text { (SSPPE_before } \\
\text { experiment) } \\
\end{array}$} \\
\hline & & flu & flex & orig & total & flu & flex & orig & total \\
\hline \multirow{2}{*}{$\begin{array}{l}\text { control } \\
\text { group }\end{array}$} & $\begin{array}{c}\text { arithmetic } \\
\text { mean }\end{array}$ & 18.6 & 14.9 & 1.32 & 35.33 & 18.9 & 15.1 & 1.12 & 35.72 \\
\hline & $\begin{array}{r}\text { standard } \\
\text { deviation }\end{array}$ & 5.23 & 4.17 & 0.91 & 10.1 & 6.71 & 5.07 & 0.86 & 12.34 \\
\hline \multirow{2}{*}{$\begin{array}{l}\text { experimental } \\
\text { group }\end{array}$} & $\begin{array}{c}\text { arithmetic } \\
\text { mean }\end{array}$ & 19.1 & 14 & 1.27 & 35.02 & 18.4 & 14.3 & 0.96 & 34.87 \\
\hline & $\begin{array}{c}\text { standard } \\
\text { deviation }\end{array}$ & 5.27 & 3.96 & 1 & 9.98 & 6.29 & 5.13 & 0.68 & 11.84 \\
\hline t-test & & 0.41 & 1.07 & 0.251 & 0.149 & 0.03 & 0.76 & 0.98 & 0.335 \\
\hline
\end{tabular}

Tab. 8 Students' creative prerequisites measured by CIRCLES test before the experiment

Differences in ex ante measurements have been in all creativity factors minimal, statistically significant. A higher average score of originality in the $\mathrm{CC}$ group has EG (Table 8) and in the SSPPE group CG (Table 8), while the differences are statistically not significant. A cross-comparison between control and experimental groups of the both studied samples shows little difference in the score of creative capacities. It, therefore, proves the equality of control and experimental groups before the experiment.

After executing the experiment on our sample, we have concluded the following results (Table 9): 


\begin{tabular}{|c|c|c|c|c|c|c|c|c|c|}
\hline \multicolumn{6}{|c|}{$\begin{array}{c}\text { CIRCLES } \\
\text { CC before and after experiment }\end{array}$} & \multicolumn{4}{|c|}{$\begin{array}{c}\text { CIRCLES } \\
\text { SSPPE before and after } \\
\text { experiment }\end{array}$} \\
\hline & & fluency & flexibility & priginality & total & fluency & flexibility & priginality & total \\
\hline \multirow{2}{*}{$\begin{array}{c}\text { experime } \\
\text { ntal } \\
\text { group } \\
\text { (ante) }\end{array}$} & $\begin{array}{c}\text { arithmetic } \\
\text { mean } \\
\end{array}$ & 19.07 & 13.99 & 1.27 & 35.02 & 18.4 & 14.33 & 0.96 & 34.87 \\
\hline & $\begin{array}{l}\text { standard } \\
\text { deviation } \\
\end{array}$ & 5.27 & 3.96 & 1 & 9.98 & 6.29 & 5.13 & 0.68 & 11.84 \\
\hline \multirow{2}{*}{$\begin{array}{c}\text { experime } \\
\text { ntal } \\
\text { group } \\
\text { (post) }\end{array}$} & $\begin{array}{c}\text { arithmetic } \\
\text { mean } \\
\end{array}$ & 22.38 & 16.82 & 2.32 & 42.04 & 22.21 & 18.35 & 2.34 & 43.86 \\
\hline & $\begin{array}{l}\text { standard } \\
\text { deviation } \\
\end{array}$ & 5.92 & 5.09 & 1.13 & 11.9 & 5.35 & 5.11 & 1.17 & 11.32 \\
\hline t-test & & $2.828 * *$ & $2.958 * *$ & $4.711 * * *$ & $3.054 * *$ & $3.102 * *$ & $3.742 * * *$ & $6.930 * * *$ & $\begin{array}{c}3.697 \\
* * *\end{array}$ \\
\hline
\end{tabular}

Tab. 9 Students' creative prerequisites measured by CIRCLES test before and after the experiment

- Ex ante and ex post measurements in the EG_CC have proved the increase of fluency mean values from 19.07 to 22.38 . The given variable has increased under the influence of the creativity development programme to a $99 \%$ with a 0.01 statistical significance level. Before the experiment, flexibility in EG_CC was around 13.99. Our experimental intention has caused the increase of this variable to 16.82 . Thus, it has achieved an increase on a 0.01 statistical significance level. Originality as the most relevant variable has not achieved a significant difference in mean values, even though by implementing the programme for creativity development its increase is on a $99.9 \%$ level of statistical significance. Overall creative abilities in EG_CC have risen from 35.02 (ex ante) to 42.04 (ex post). It represents a highly increased score on a $0.01 \%$ statistical significance level. By implementing the creativity development programme in EG_CC, all analysed variables by means of the Circle test have significantly increased, thus proving hypothesis 2.

- In ex ante and ex post measurements in EG_SSPPE we have observed the increase of mean values in fluency from 18.40 before the experiment to 22.21 after executing the experiment. We have achieved a difference on a 0.01 statistical significance level. The development of flexibility 
has been even more successful as its mean value has shifted from 14.33 to 18.35 on a 0.001 statistical significance level. Originality has a similar statistical significance level. The mean value in original figural drawings has increased from 0.96 to 2.34 . The difference in values has a $99.9 \%$ of statistical significance level. Since the overall creative performance has marked statistical significant differences, we can conclude that also the third hypothesis has been proved.

To conclude the experiment, we compare ex post measurements between CG and EG (Table 10).

\begin{tabular}{|c|c|c|c|c|c|c|c|c|c|}
\hline \multicolumn{4}{|c|}{ CIRLES (CC_CG_EG after experiment) } & \multicolumn{5}{c|}{$\begin{array}{c}\text { CIRLES (SSPPE after } \\
\text { experiment) }\end{array}$} \\
\hline \hline & & fluency & lexibility & riginality & total & fluency & lexibility priginality & total \\
\hline \hline \multirow{2}{*}{$\begin{array}{c}\text { control } \\
\text { group }\end{array}$} & $\begin{array}{c}\text { arithmetic } \\
\text { mean }\end{array}$ & 18.57 & 14.23 & 1.37 & 34.6 & 18.8 & 15.2 & 1.18 & 35.72 \\
\cline { 2 - 10 } & $\begin{array}{c}\text { standard } \\
\text { deviation }\end{array}$ & 5.68 & 5.12 & 1.02 & 11.62 & 5.53 & 4.66 & 0.93 & 10.96 \\
\hline \hline $\begin{array}{c}\text { experime } \\
\text { ntal } \\
\text { group }\end{array}$ & $\begin{array}{c}\text { arithmetic } \\
\text { mean }\end{array}$ & 22.38 & 16.82 & 2.32 & 42.04 & 22.2 & 18.4 & 2.34 & 43.86 \\
\cline { 2 - 10 } & $\begin{array}{c}\text { standard } \\
\text { deviation }\end{array}$ & 5.92 & 5.09 & 1.13 & 11.9 & 5.35 & 5.11 & 1.17 & 11.32 \\
\hline \hline t-test & & $\begin{array}{c}3.405 \\
* * *\end{array}$ & $\begin{array}{c}5.440^{*} \\
* *\end{array}$ & $\begin{array}{c}11.900^{*} \\
* *\end{array}$ & $\begin{array}{c}3.039 \\
* * *\end{array}$ & & & & \\
\hline
\end{tabular}

Tab. 10 Students' creative prerequisites measured by CIRCLES test after the experiment

Differences between EG_CC and CG_CC are more obvious than in EG before and after the experiment. While the mean value in fluency in CG was 18.57, in ex post measurement in EG it was 22.38. Differences on a 0.001 significance level have been demonstrated also in flexibility, originality and the overall score in creative abilities (Table 18). These results prove hypothesis 3.

Differences between EG_SSPPE and CG_SSPPE are as follows (Tab. 10):

Fluency and flexibility have in comparison between the control group and experimental group increased on a 0.01 significance level. The data are similar to those from ex ante and ex post measurements in the experimental group as these were quite equal. A more relevant difference has been achieved in case of originality and the overall creative performance where the statistical significance of differences oscillates at $99.9 \%$.

Conclusions from the verification of hypothesis 3 :

- This experiment aimed at testing the effectiveness of our Creative Teacher programme for creativity development in the experimental 
groups of undergraduate teacher training has proved a significant increase of creativity. Having experienced the development of individual elements of creative performance, we can claim this hypothesis has been proved. The score of experimental group in ex ante and ex post measurements has risen and at the same time, respondents' creativity (EG over CG) has statistically changed. The effectiveness of the programme has been demonstrated in all factors of creativity, mainly in fluency, flexibility and originality. We can confirm the influence of our programme on the development of creative abilities as demonstrated by Circle test in both experimental groups of CC and SSPPE.

These observed changes in creative performance and overall abilities of the undergraduate student teachers are raison d'être of creative education which should be performed chiefly by future teachers. A traditional understanding of education, on the other hand, impedes a creative potential as the stereotype does not take concern in subjective formation.

\section{Discussion}

Current requirements for a teacher's personality are based on humanization of education conditions and his own creativization. Therefore, a new requirement for modernization of the content and methods applied in undergraduate teacher training has emerged. Also our research was conducted in this sense. Our intention was to find the level of students' motivation for learning, performance and how their creative thinking and skills can be stimulated. Our experiment was oriented on the development of motivation in learning and creativity. We studied cognitive, effective and affective motivation out of which the highest score has been seen in cognitivization leading to creativity. The gained data prove our hypothesis in which we state that motivation in creativity can be developed by implementing a programme for developing creativity.

Creativity was a significant watched variable. No matter how we call it in the context with personality - creative ability or creative performance - it is in a relation with this very personality, its life and utterly significant for the one's fulfilling existence.

Creative ability and performance in our experiment were analysed by using Circles test. Individual factors of creativity - fluency, flexibility and originality were stimulated by implementing the Creative Teacher programme. In our experiment we managed to increase all studied variables on a statistical significance level, thus giving a proof to our hypothesis.

It was our attempt to evaluate the effectiveness of the creativity development programme in undergraduate teacher training regardless learning outcomes. 


\section{Conclusions}

In conclusion we observe that our goals have been fulfilled as follows:

The basic goal was to prove the effectiveness and significant influence of the Creative Teacher programme on increase of motivation and creativity. We have proved the Creative Teacher programme significantly influences both creativity and motivation of future teachers. As it follows from the results, the Creative Teacher programme is effective bringing a significant improvement in creativity and motivation of the students in EG.

The secondary goal was to formulate information on reliability of applied methods. We can say that all of them have demonstrated a normal distribution of score at mean values (but some subtests of Circle creativity test). Data, especially in $\mathrm{CG}$, prove a good reliability of the applied methods. Due to intentional changes in EG the situation was different and therefore we think it is not correct to observe reliability in this group, but rather confirm our intention to make these expected changes to happen.

A more general goal of this study was to demonstrate new knowledge on more effective planning of teaching strategies that would increase the creativity and motivation of undergraduate students of teacher training becoming thus important components and part of creative teaching concept. We hope our findings and their interpretation will become an inspiration for others working in this sphere.

\section{References}

BIEHLER, F. - SNOWMAN, I. J.: Psychology Appplied to teaching. Boston: Houghton Mifflyn Company 1990.

DARGOVÁ, J.: Tvorivé kompetencie učitel'a. Prešov: Privatpress s.r.o., 2001.

DARGOVÁ, J.: Tvorivost' v pregraduálnej príprave učitel'ov. In: Pedagogická revue, vol. 55, 2003, vol.1, p. 71-85.

HECKHAUSEN, H.: Motivation und Handeln. Berlin: Springer - Verlag, 1989.

Higher Education in Europe 2009: Developments in the Bologna Process. Brussels: Eurydice, 2009. [online]. [cit. 2012-09-16]. http://eacea.ec.europa.eu/portal/page/portal/Eurydice/showPresentation? pubid $=099 \mathrm{EN}$

Higher Education in Europe 2009: Developments in the Bologna Process. Brussels: Eurydice, 2009. [online]. [cit. 2012-09-16]. http://eacea.ec.europa.eu/portal/page/portal/Eurydice/showPresentation?pubid= 099EN

HLAVSA, J. et al.: Psychologické problémy výchovy $k$ tvořivosti. Praha: SPN, 1981. HLAVSA, J.: Psychologické základy teorie tvorby. Praha: Academia, 1985. 
HVOZDÍK, J. - ZELINA, M.: K metodologickým otázkam rozvíjajúcich programov z hl’adiska školskej a poradenskej psychológie. In: Českoslovenká psychologie, vol. 27, vol.3, 1983. p. 203-208.

HRABAL, V. et al.: Psychologické otázky motivace ve škole. Praha: SPN, 1989. ISBN 80-04-23487-9-6.

JOHNSON, T. R. - JOHNSON, W. D.: An Overview Of Cooperative Learning. Baltimore: Brookes Press, 1994. [online]. [cit. 2012-09-16]. http://www.cooperation.org/pages/overviewpaper.html

JURČOVÁ, M.: Tvorivost' učitel'ov a žiakov v Torrancovom neverbálnom teste. In: Psychológia a patopsychológia diet'at’a, 1979, p. 321-336.

JURČOVÁ, M.:. Torranceho figurálny test tvorivého myslenia. Praktická čast'. Bratislava: Psychodiagnostické a didaktické testy, 1984.

JURČOVÁ, M. et al.: Dimenzie a bariéry tvorivej klímy. In: Studia psychologica, vol. 35, 1993, n.1, p. 33-41.

KÖNIGOVÁ, M.: Tvořivost. Praha: Grada, 2007.

KUSÁ, D. et al.: Zjavná a skrytá tvorivost'. Bratislava: Ústav experimentálnej psychológie SAV, 2006. LUKÁŠOVÁ - KANTORKOVÁ, H. (ed.): Př́prava učitelu pro primární vzděláváni v ČR a budoucí plánováni scénárù v Evropè. Ostrava: $\mathrm{PF}$ OU, 2004.

MADSEN, K. B.: Moderní teorie motivace. Praha: Academia, 1979

MARUŠINCOVÁ, E.: Učebná motivácia - problémy jej identifikácie a vzt’ahu k školskej práci. In: Psychológia a patopsychológia dietata, 1989, n. 5, p. 431 441.

OLIVER, M. R. - RESCHLY, J. D.: Effective Classroom Management: Teacher Preparation and Professional Development. Washington: Vanderbilt University, 2007. [online]. [cit. 2012-09-16]. http://www.teachingquality.org/legacy/brief trust2007.pdf

PARDEL, T.: Motivácia ludskej činnosti a správania. Bratislava, SPN, 1977.

SOLLÁROVÁ, E.: Výsledky aplikácie programov tvorivosti u žiakov ZŠ. In: Psychológia a patopsychológia diet’at'a, vol. 20, 1985, n. 2, p. 159-169.

STERNBERG, J. R. - LUBART, I. T.: Investing in creativity. In: American Psychologist, vol. 51, n.7, 1996, p. 677-688.

STERNBERG, J. R. - O'HARRA, A. L. - LUBART, I. T.: Creativity as Investment. In: California Management Review, 1997, vol. 40, n. 1, p. 8-21.

SZOBOIOVÁ, E.: Tvorivost', od záhady k poznaniu. Bratislava: Stimul, 2004.

ŠVEC, V.: Monitorování a rozvoj pedagogických dovednosti. Brno: Paido, 2000.

TORRANCE, E. P.: The nature of creativity. Contemplate psychological perspectives. Cambridge: Camle University press, 1988.

ZELINA, M.: Program rozvoja tvorivosti žiakov: konštrukcia a výsledky použitia. In: Československá psychológia, vol. 26, n. 2, 1982. p. 145-155.

ZELINA, M.: Výchova tvorivej osobnosti. Bratislava: UK, 1995. 